\title{
Altered mucosal immune response after acute lung injury in a murine model of Ataxia Telangiectasia
}

\author{
Olaf Eickmeier ${ }^{*}$, Su Youn Kim', Eva Herrmann², Constanze Döring ${ }^{3}$, Ruth Duecker ${ }^{1}$, Sandra Voss' ${ }^{1}$, Sibylle Wehner ${ }^{4}$, \\ Christoph Hölscher ${ }^{5}$, Julia Pietzner', Stefan Zielen ${ }^{1}$ and Ralf Schubert ${ }^{1}$
}

\begin{abstract}
Background: Ataxia telangiectasia (A-T) is a rare but devastating and progressive disorder characterized by cerebellar dysfunction, lymphoreticular malignancies and recurrent sinopulmonary infections. In A-T, disease of the respiratory system causes significant morbidity and is a frequent cause of death.

Methods: We used a self-limited murine model of hydrochloric acid-induced acute lung injury (ALI) to determine the inflammatory answer due to mucosal injury in Atm (A-T mutated)- deficient mice ( $\mathrm{Atm}^{-1-}$ ).

Results: ATM deficiency increased peak lung inflammation as demonstrated by bronchoalveolar lavage fluid (BALF) neutrophils and lymphocytes and increased levels of BALF pro-inflammatory cytokines (e.g. IL-6, TNF). Furthermore, bronchial epithelial damage after ALI was increased in $\mathrm{Atm}^{-1-}$ mice. ATM deficiency increased airway resistance and tissue compliance before ALI was performed.

Conclusions: Together, these findings indicate that ATM plays a key role in inflammatory response after airway mucosal injury.
\end{abstract}

Keywords: Ataxia telangiectasia, ATM, Acute lung injury, Inflammation

\section{Background}

Ataxia telangiectasia (A-T) is a severe autosomal recessive disorder that is caused by mutations in the ATM gene which codes for ataxia telangiectasia mutated (ATM), a pleiotropic kinase involved in DNA doublestrand break recognition, activation of DNA repair proteins, and signaling in cell cycle checkpoint control [1-5]. This rare human disease encompasses defects in $\mathrm{T}$ - and B- cell maturation, cerebellar degeneration, radiosensitivity, and increased susceptibility to malignancies, especially lymphomas [6-11]. The majority of patients suffers from IgA and IgG subclass deficiency and has impaired antibody responses to pneumococcal antigens $[12,13]$. Immunodeficiency is considered to be the primary factor predisposing these patients to the development of chronic respiratory tract infections. The 20 year survival rate is $53.4 \%$, and death is predominantly caused by lung failure and cancer. The prognosis has not changed since 1954 [14].

\footnotetext{
* Correspondence: olaf.eickmeier@kgu.de

${ }^{1}$ Pediatric Pulmonology, Allergy and Cystic Fibrosis, Johann Wolfgang

Goethe- University, Theodor-Stern-Kai 7, Frankfurt D-60590, Germany

Full list of author information is available at the end of the article
}

Atm- deficient $\left(\mathrm{Atm}^{-/-}\right)$mice exhibit similar defects as A-T patients [9,15-19] and have been useful for studying A-T, mechanisms of DNA damage responses, and oncogenesis.

Lung disease is common in patients with $\mathrm{A}-\mathrm{T}$ and often progresses with age and neurological decline [20]. Three major types of lung disease are generally recognized in A-T patients: Recurrent sinopulmonary infections and bronchiectasis, interstitial lung disease (ILD)/ pulmonary fibrosis and lung disease associated with neuromuscular deficits due to bulbar and spinal system impairment [20-24]. An evaluation of a series of patients with A-T showed an increased frequency and severity of signs and symptoms of impaired deglutition and an association between dysphagia, aspiration and pulmonary disease of these patients was confirmed [25]. Clarifying the impact of cellular and clinical factors on A-T lung disease and its progression may help with discovery and development of therapeutic interventions.

Aspiration pneumonitis is one of the leading causes of Acute Lung Injury (ALI)/ Acute Respiratory Distress Syndrome (ARDS) that is in most instances self-limited, 
suggesting the existence of endogenous, host protective mechanisms [26]. Here, in a non-lethal model of ALI [27,28], $\mathrm{Atm}^{-1}$ mice were challenged with intratracheal application of hydrochloric acid $(\mathrm{HCl})$ in order to examine if host protective mechanisms are disturbed after mucosal injury.

\section{Methods}

\section{Animal model}

All mice were maintained under specific pathogen-free conditions and were checked daily. All studies were reviewed and approved by the German Animal Subjects Committee (Gen.Nr.F133/10). We used 10-12 week-old, male $\mathrm{Atm}^{-1-}$ mice $\left(\mathrm{Atm}^{\mathrm{tm} 1 \mathrm{Awb}}\right)$, in a $129 \mathrm{SvEv}$ background [18], kindly provided by A. Wynshaw-Boris, School of Medicine, University California San Diego, USA, were used as animal model. Weights of the $\mathrm{Atm}^{-/-}$mice $(20 \mathrm{~g} \pm 0.4$ $(\mathrm{n} \geq 5)$; mean \pm S.E.M.) were different from the wild type animals $(24 \mathrm{~g} \pm 0.8$; $(\mathrm{n} \geq 5)$; mean \pm S.E.M.; $\mathrm{p}<0.01)$.

\section{Acid-initiated acute lung injury (ALI) and treatment with AT-RVD1}

Hydrochloric acid $(0.1 \mathrm{~N} \mathrm{HCl}, \mathrm{pH}$ 1.5, $50 \mu \mathrm{l}$, endotoxin free; Sigma-Aldrich) was instilled selectively into the left mainstem bronchus of anesthetized mice via a 24-gauge angiocatheter inserted intratracheally. Due to high mortality rate in the $\mathrm{Atm}^{-/-}$mice, the experimental setting was changed to instillation of $1 \mu \mathrm{l} / \mathrm{g}$ body weight of $0.1 \mathrm{~N} \mathrm{HCl}$ ( $\mathrm{pH} 1.5)$ into the left mainstem bronchus of anesthetized mice. At different time points (24 hours and 1 week) after acid instillation, bilateral bronchoalveolar lavage (BAL) was performed with 2 aliquots of $1 \mathrm{ml}$ of PBS plus $0.6 \mathrm{mM}$ EDTA. The total cell counts and leukocyte differential in BAL fluids (BALFs) were determined as previously described [28]. Briefly, total cells in BALFs were counted using a hemocytometer, and differential cell counts were determined after cytospin using Wright-Giemsa staining.

\section{Histology and immunohistochemistry}

Mice were anesthetized with an intraperitoneal Ketamin-Rompun mixture (20\% Ketamin, CuraMED GmbH, Karlsruhe, Germany; 8\% Rompun, Bayer Vital GmbH, Leverkusen,Germany) injection. They were perfused transcardially with $4 \%$ paraformaldehyde in PBS. Lung tissue sections were prepared from fixed, paraffin-embedded organs and stained with either hematoxylin and eosin (H\&E) or a special mucous staining, namely Alcian blue and van Giesona (ABvG).

\section{Measurement of lung mechanics}

For measurement of tissue elastance and lung resistance, mice were anesthetized and mechanically ventilated with a flexiVent small animal ventilator (SCIREQ, Montreal, Canada). Lung mechanics were determined in anesthetized, ventilated animals.

\section{Mediator levels in BALFs}

Select cytokines and chemokines were measured in aliquots of BALF by cytometric bead array as described [29].

\section{Statistical analysis}

Data are expressed as mean values \pm S.E.M. unless otherwise indicated. A two factorial analysis of variance of the logarithmized cell counts with interactions was used discriminate between differences caused by experimental conditions over time and those caused by experimental groups with the corresponding F test. Gauss distribution of the residuals was checked with the Shapiro-Wilk test.

Parametric or nonparametric analysis of variance was used to determine significance for differences between more than 2 groups as appropriate. For analyses between 2 groups, cohorts were compared by Mann-Whitney-U- test. Significance was determined with $\mathrm{P}$ values $\leq 0.05$. Statistics were performed using GraphPad Prism 5 for Windows (San Diego, CA, USA).

\section{Results}

$\mathrm{Atm}^{-/-}$deficient mice show elevated sensitivity to airway mucosal injury

In an in vivo setting we examined the role of ATM in the pathogenesis of airway mucosal injury due to ALI. In order to measure the inflammatory and resolutional response after acute lung injury, $50 \mu \mathrm{l}$ of hydrochloric acid (0.1 N HCl, pH 1.5) was instilled into the left mainstem bronchus. Remarkably, Atm ${ }^{-1-}$ mice showed elevated mortality due to airway $\mathrm{HCl}$ exposure in a defined mild injury experimental setting $[27,28]$ in comparison to healthy control mice (Figure 1). A mortality rate of $60 \%$

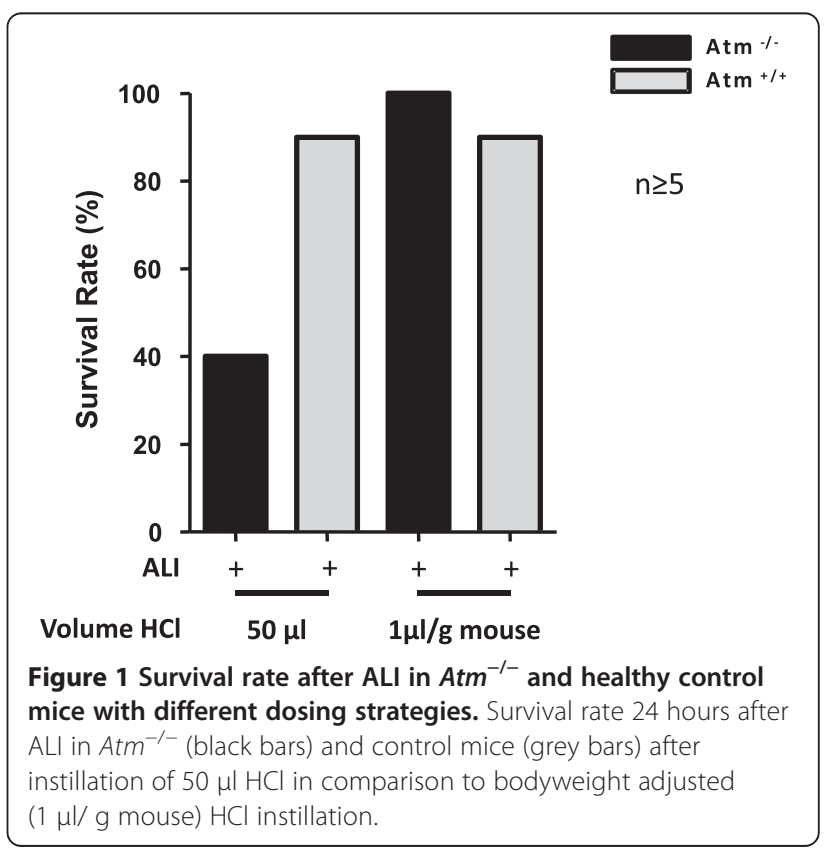


in the $\mathrm{Atm}^{-1-}$ group ( $\left.\mathrm{n}>5\right)$ in comparison to a mortality rate of $10 \%$ in the control group $(n>5)$ was the reason for changing the injury protocol. So we adjusted the acid dosage to the body weight of the mice. In particular, we injected $1 \mu \mathrm{l} / \mathrm{g}$ body weight of hydrochloric acid into the left mainstem bronchus and thus increased the survival rate in the $\mathrm{Atm}^{-/-}$group to $100 \%$ (Figure 1).

\section{Defective ATM increases leukocyte recruitment after airway mucosal injury}

To determine the effects of ATM on host responses to mucosal injury, BAL was performed on different time points after instillation of hydrochloric acid $(0.1 \mathrm{~N} \mathrm{HCl}$, $\mathrm{pH} 1.5$ ) into the left mainstem bronchus (Figure 2a-f and Figure 3a). There was a significant change in total BALF cell numbers after ALI $(p=0.017)$. Total BALF cell numbers 24 hours after ALI in $\mathrm{Atm}^{-1-}$ mice (70.130 total BALF cells $\pm 14.630(n=5)$; mean \pm S.E.M.) were larger than in healthy control mice (24.840 total BALF cells \pm 5898; $(\mathrm{n}=4)$; mean \pm S.E.M.) (Figure $3 \mathrm{~b}-\mathrm{d})$ but this difference was not significant in two-factorial ANOVA. There was no significant difference in total leukocyte and differential cell count between $\mathrm{Atm}^{-1-}$ mice before (Figure 3b and Figure $4 \mathrm{a}, \mathrm{d}, \mathrm{g}$ ) or one week after (Figure $3 \mathrm{~d}$ and Figure $4 \mathrm{c}, \mathrm{f}$, i) ALI. However, 24 hours after injury $\mathrm{Atm}^{-/}$mice showed increased BALF neutrophils (PMNs) (30.300 PMNs \pm $11.210(\mathrm{n}=5)$; mean \pm S.E.M. $)$ as compared to healthy control mice (1.220 PMNs $\pm 647(\mathrm{n}=4)$; mean \pm S.E.M. $)$ (Figure 4b). Difference over time after injury as well as interactions between $\mathrm{Atm}^{-/-}$mice and control mice were significant here $(\mathrm{p}<0.001$ and $\mathrm{p}=0.012$, respectively). BALF lymphocytes were also increased in $\mathrm{Atm}^{-1}$ mice (179 lymphocytes $\pm 43 ; \quad(n=5)$; mean \pm S.E.M. $)$ and in healthy control mice (34 lymphocytes $\pm 34, n=4$, mean \pm S.E.M.; $p=0.042$ for time-effect in two- factorial ANOVA) (Figure 4e). There were no significant differences in the number of macrophages 24 hours after ALI in $\mathrm{Atm}^{-/-}$mice compared to control mice (Figure 4h).

\section{ATM deficiency impacts the lung histopathological} changes after acid- initiated acute lung injury (ALI) Acute lung injury due to $\mathrm{HCl}$ acid instillation led to increased epithelial disruption 24 hours after exposure to acid in $\mathrm{Atm}^{-1}$ mice relative to control mice (Figure 5a-d). One week after mucosal injury $\mathrm{Atm}^{-1-}$ mice showed hyperemic lung tissue (Figure 5e) and increased mucus production (Figure $5 \mathrm{~g}$ ) in comparison to control mice (Figure $5 f$ and $h$ ).

\section{ATM deficient mice show elevated airway resistance and decreased tissue compliance}

To investigate whether ATM deficiency had a measurable effect on lung mechanics, we determined lung function in mechanically-ventilated, anesthetized mice. Possibly because of the unilateral and mild nature of the ALI in this model, marked changes in airway resistance (Figure 6a) and tissue compliance (Figure $6 \mathrm{~b}$ ) were not observed and no significant differences were evident with ATM

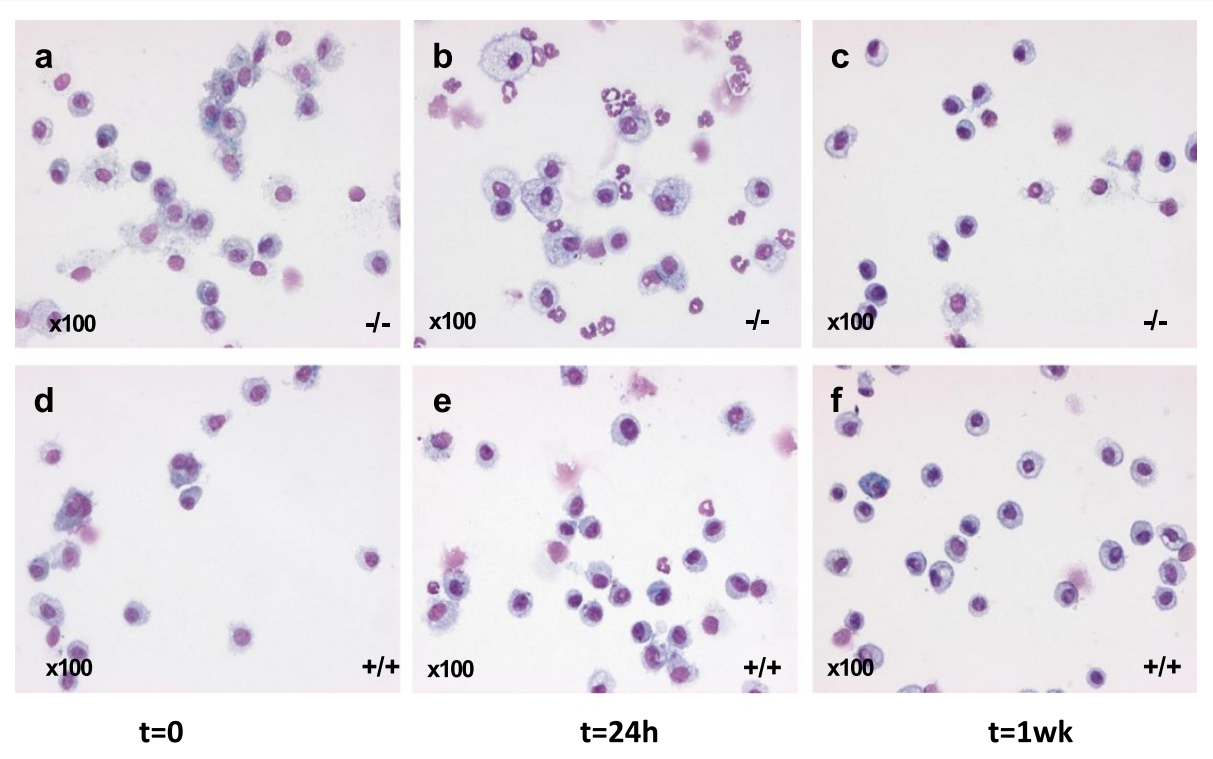

Figure 2 Leukocyte clearance after airway mucosal injury in $\mathrm{Atm}^{-/-}$and healthy control mice. BALF cell differentiation before ALI between $\mathrm{Atm}^{-1-}$ (a) and control mice (d). Atm ${ }^{-1-}$ mice show decreased PMNs clearance (b) 24 hours after ALI representing increased inflammation and disturbed resolution compared to control mice (e). These differences have resolved 1 week after ALI (c and f). Atm ${ }^{-1-}$ mice (a-c), Atm ${ }^{+/+}$mice (d-e). Original magnification $\times 100$. 

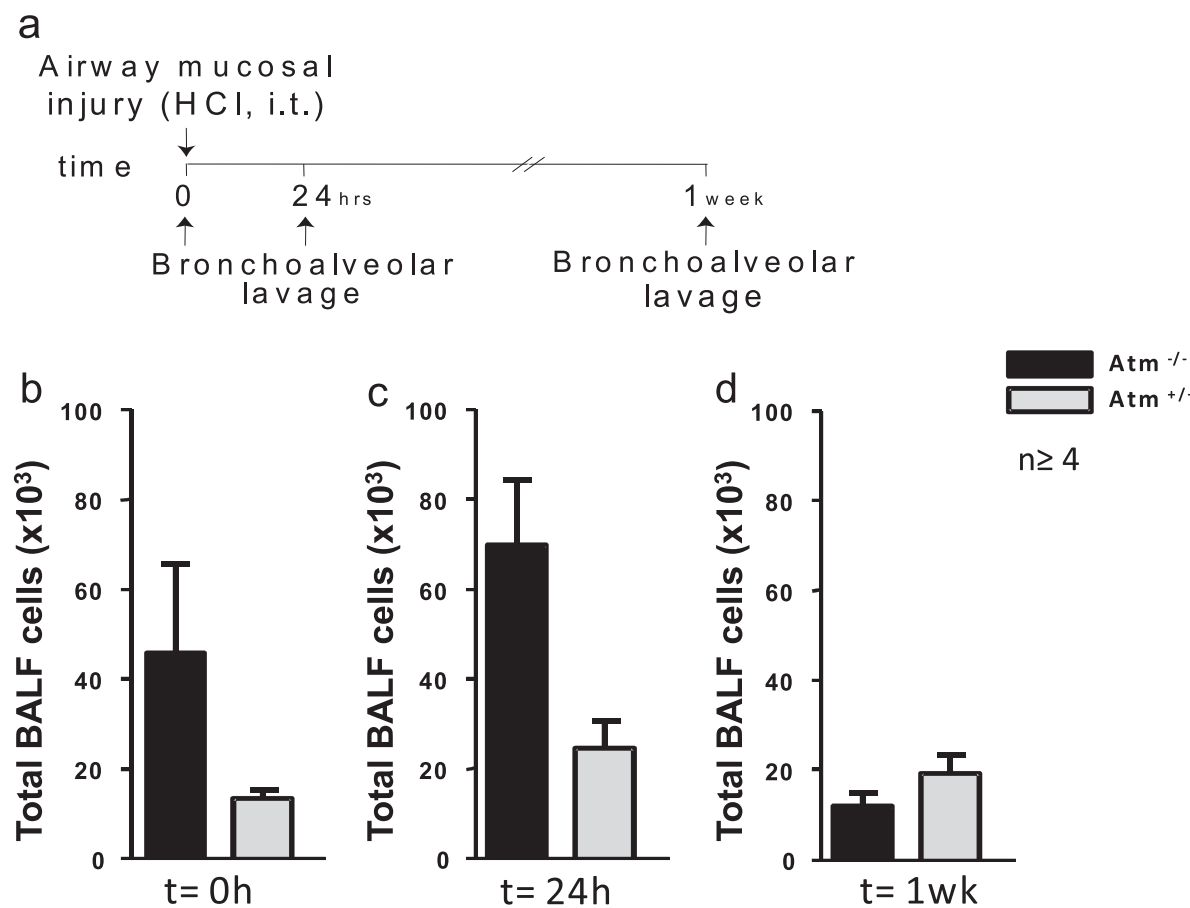

Figure 3 ATM deficiency increases leukocyte recruitment after airway mucosal injury. (a) $\mathrm{Atm}^{-1-}$ mice or control mice underwent acute lung injury (ALI) by intratracheal (i.t.) instillation of $\mathrm{HCl}$ and bronchoalveolar lavage (BAL) was performed at different time points. Before ALI (b), 24 hours after ALI (c) and one week after ALI (d) BAL was performed and total cells (b-d) were enumerated (see Methods). Values represent the mean \pm S.E.M. for $n \geq 4$ mice.

deficiency 24 hours after ALI (Figure 6a and b). Of interest, the $\mathrm{Atm}^{-/}$mice showed increased lung resistance (1.1 $\left.\mathrm{cmH}_{2} \mathrm{O} * \mathrm{~s} / \mathrm{ml} \pm 0.12,(\mathrm{n}=5)\right)$ and decreased tissue compliance $\left(0.02 \mathrm{cmH}_{2} \mathrm{O} / \mathrm{ml} \pm 0.003,(\mathrm{n}=5)\right)$ before mucosal damage was performed in comparison to control mice (resistance: $0.57 \mathrm{cmH}_{2} \mathrm{O} * \mathrm{~s} / \mathrm{ml} \pm 0.03$, mean \pm S.E.M., $(\mathrm{n}=6)$, $p<0.001$; compliance $\left(0.04 \mathrm{cmH}_{2} \mathrm{O} / \mathrm{ml} \pm 0.002\right.$, mean $\pm \mathrm{S}$. E.M., $(\mathrm{n}=6), p<0.005)$ (Figure 6a and $\mathrm{b}$ ).

\section{ATM deficiency enhances pro-inflammatory mediator re- lease after ALI}

To identify anti-inflammatory or pro-resolving mechanisms for ATM in ALI, BALF levels of several cytokines were determined by cytometric bead array. BALF IL-6 (Figure 7a) and TNF- $\alpha$ (Figure 7b) was significantly increased in $\mathrm{Atm}^{-/-}$mice 24 hours after ALI. BALF levels of other mediators did not increase with Atm deficiency relative to healthy control mice. No significant changes were observed in BALF for IL-10, IL-4, IL-12p40, IL$17 \mathrm{~A}$ and IFN- $\gamma$ (data not shown).

\section{Discussion}

Lung disease is a common feature in patients with A-T and often progresses with age and neurological decline [20]. Diseases of the respiratory system cause significant morbidity and are a frequent factor or cause of death in the A-T population [20,30-32]. Several factors contribute to the increased susceptibility to respiratory infections. Immunodeficiency may be one, but not the only, etiology for lung disease in A-T. Low levels of pneumococcal antibodies and diminished levels of IgG subclasses are hallmarks of A-T and associated with respiratory tract infection frequency. However, not all respiratory tract infections in A-T are solely due to immunodeficiency $[13,32]$. Abnormal injury repair, premature aging, systemic inflammation, and oxidative stress are confirmed to contribute to the pathophysiology and disease progression in A-T lung disease and pulmonary disorders [33]. However, little is known about injury and host protective mechanisms in A-T lung disease. Furthermore, dysphagia in patients with A-T is a well known clinical symptom [25]. Similar to lung disease, this problem appears to be progressive and the assumption that swallowing function worsens with age is consistent with the progression of neurodegeneration and the bulbar impairments associated with A-T [5]. The impact of cellular and clinical factors on A-T lung disease is unknown so far. In our study, we investigated a pathogen-independent damage in order to determine differences in host mucosal inflammatory and repair mechanisms in $\mathrm{Atm}^{-/-}$mice in comparison to control mice. Interestingly, $\mathrm{Atm}^{-/-}$mice did not 

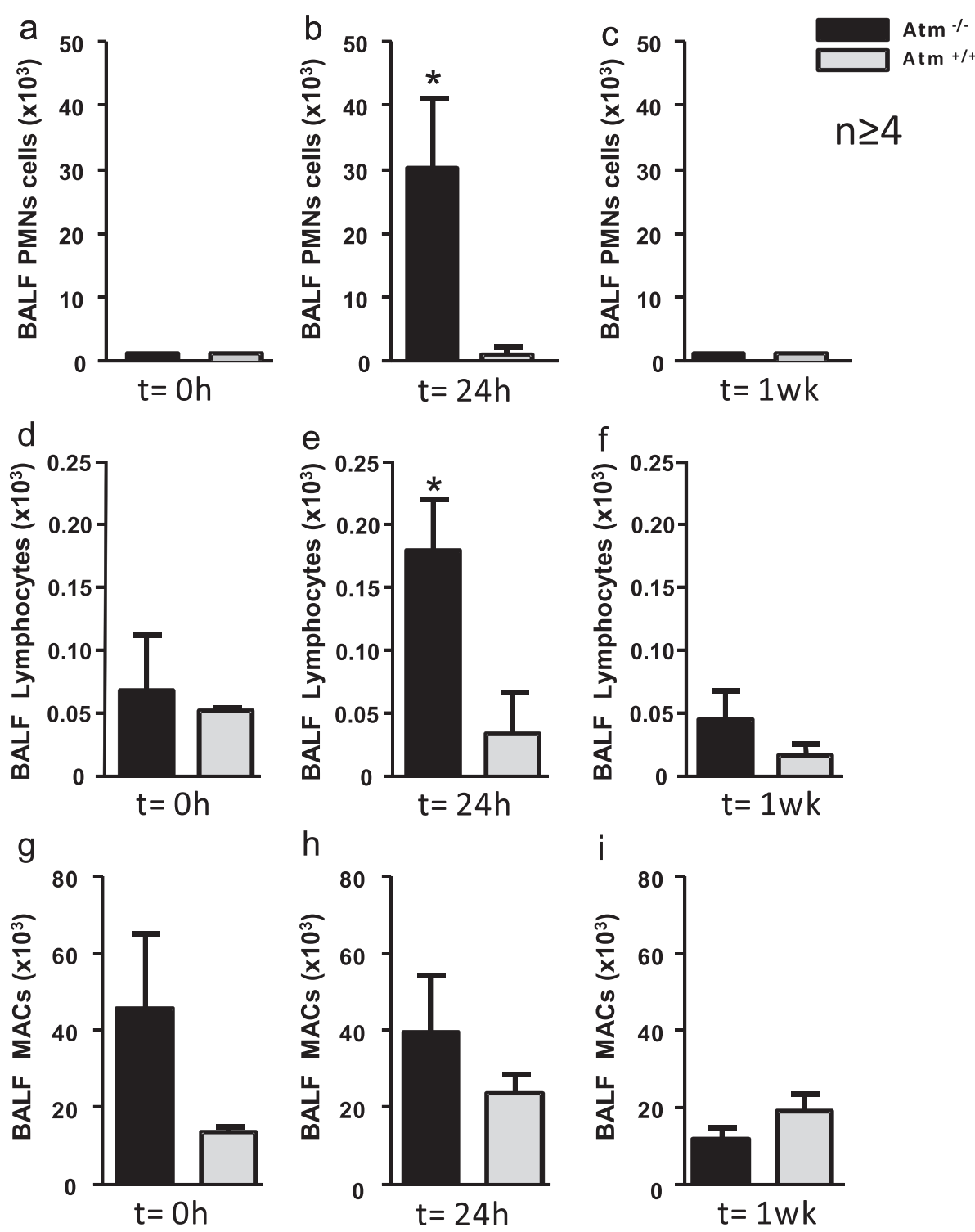

h

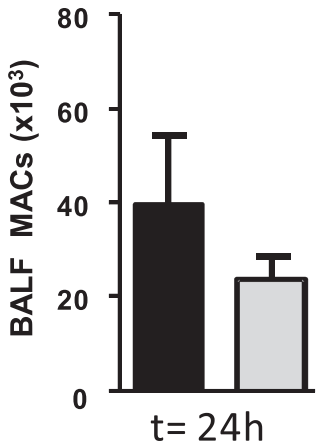

i

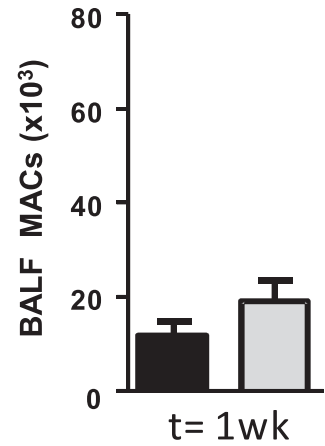

Figure 4 ATM deficiency increases polymorphonuclear leukocytes (PMNs) and lymphoytes recruitment after airway mucosal injury. $\mathrm{Atm}^{-1-}$ or control mice underwent acute lung injury (ALI) by i.t. instillation of $\mathrm{HCl}$ and bronchoalveolar lavage (BAL) was performed at different time points. Before ALI (a, $\mathbf{d}, \mathbf{g}), 24$ hours after ALI (b, e, h) and one week after ALI $(\mathbf{c}, \mathbf{f}, \mathbf{i})$ BAL was performed and differential cell count for PMNs (a-c), lymphocytes (d-f) and macrophages (MACs) (g-i) was done. Values represent the mean \pm S.E.M. for $n \geq 4$ mice. * $P<0.05$ vs. vehicle group.

show any clinical symptoms except for smaller size at birth and a slower growth rate compared to the wild-type littermates [34]. However, when challenged with hydrochloric acid, causing a disruption in the integrity of the airway epithelial barrier, we showed that $\mathrm{Atm}^{-/}$mice exhibit greater severity of clinical symptoms and mortality rates as well as airway recruitment of peripheral leukocytes, and mount an even stronger immune response characterized by inflammatory biomarkers compared with wild-type mice. This is in accordance with the finding that A-T patients do exhibit elevated serum IL-8 levels, reflecting a systemic inflammation contributing to disease phenotype [35]. Since weights of the $\mathrm{Atm}^{-/-}$mice were less in comparison to wild-type mice, initial application of $50 \mu \mathrm{l}$ hydrochloric acid may have shown a high mortality rate in $\mathrm{Atm}^{-/}$mice due to a higher volume per body weight. So we adjusted the application of hydrochloric acid volume to the body weight of the mice.

Epithelial damage, PMN recruitment and activation of host protective mechanisms are early events in acute mucosal inflammation and ALI/ARDS. In this study, we confirmed the pivotal role of ATM in decreasing the 

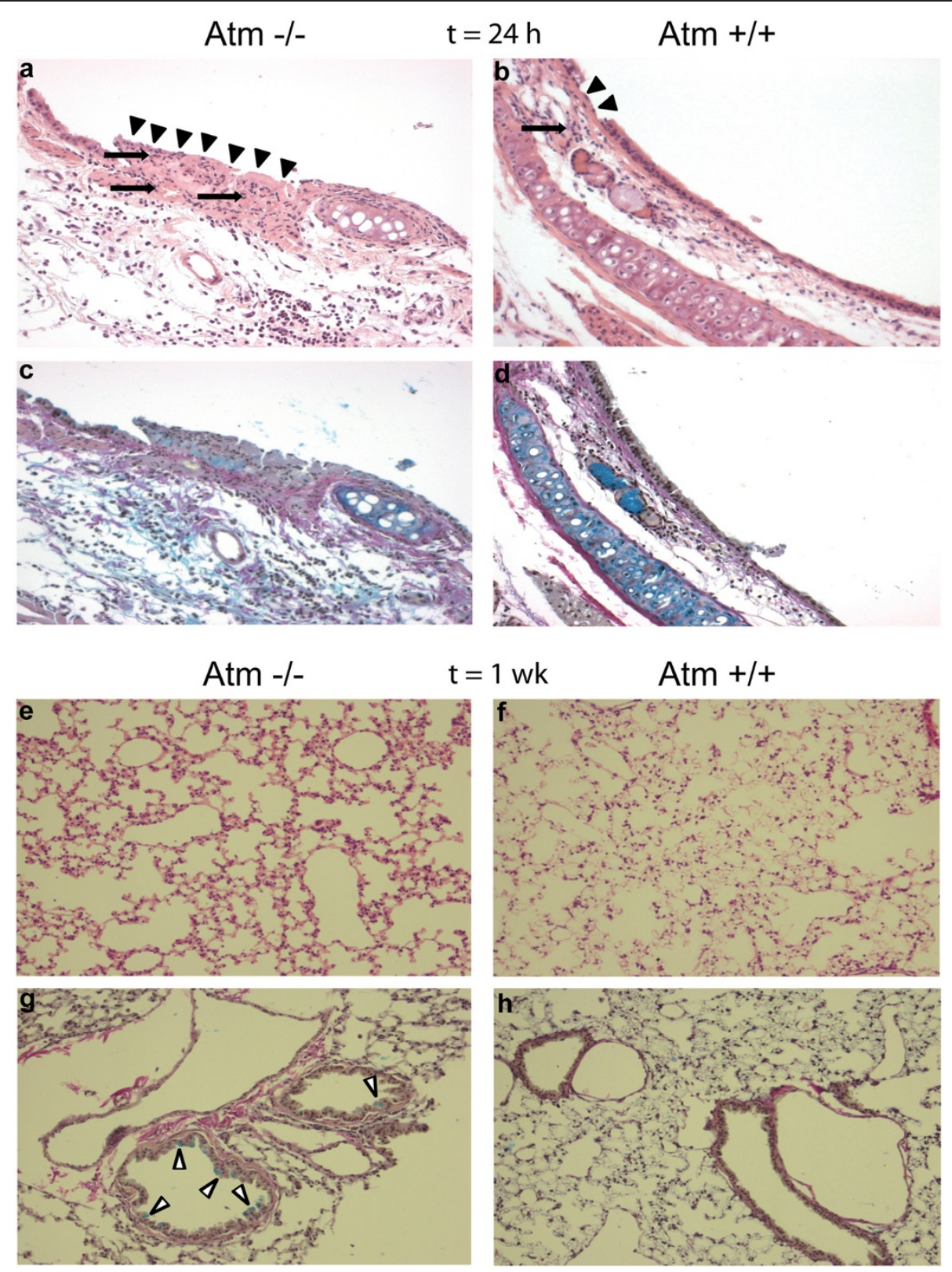

Figure 5 ATM deficiency impacts the lung histopathological changes after acid -initiated acute lung injury (ALI). Lung tissue sections were obtained 24 hours after (a-d) and one week after (e-h) ALI from $\operatorname{Atm}^{-1-}(\mathbf{a}, \mathbf{c}, \mathbf{e}, \mathbf{g})$ and control mice (b, $\left.\mathbf{d}, \mathbf{f}, \mathbf{h}\right)$. Hematoxylin and eosin (H\&E) (a, b, e, f) or ABvG (c, $\mathbf{d}, \mathbf{g}, \mathbf{h})$. Results are representative of $n=3$. Black arrowheads, epithelial cell disrupture; white arrowheads, mucus; black arrows, inflammatory cells. Original magnification $\times 200$.

severity of $\mathrm{HCl}$ acid-initiated ALI. ATM deficiency favored disruption of epithelial barrier integrity after ALI, as indicated by histological findings, and BALF biomarkers, namely IL- 6 and TNF- $\alpha$. In addition, we found an elevation in lung resistance and reduction in tissue compliance before intratracheal administration of $\mathrm{HCl}$ that was not altered after ALI. This data is in accordance with pulmonary function testing (PFT) in A-T patients $12-20$ years of age, showing a mixture pattern of obstructive and restrictive lung disease $[21,24,36]$. The current study explored for the first time the inflammatory response of airway mucosa after injury by $\mathrm{HCl}$. In accordance with human studies showing early structural changes, particulary bronchiectasis and consolidation [37], our $\mathrm{Atm}^{-1}$ mice showed decreased compliance and increased obstruction before musosal injury occurred. This is highly suggestive for the role of ATM for epithelial cell integrity homeostasis. 


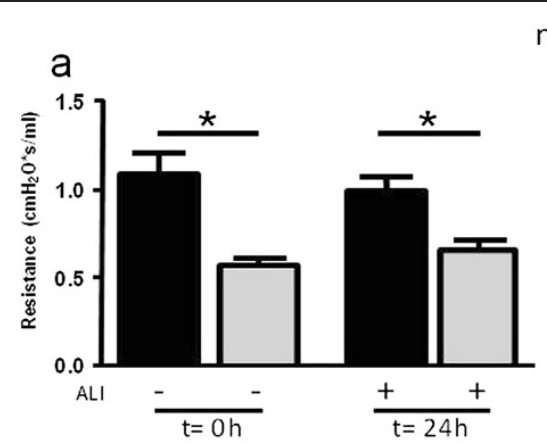

$n \geq 5$

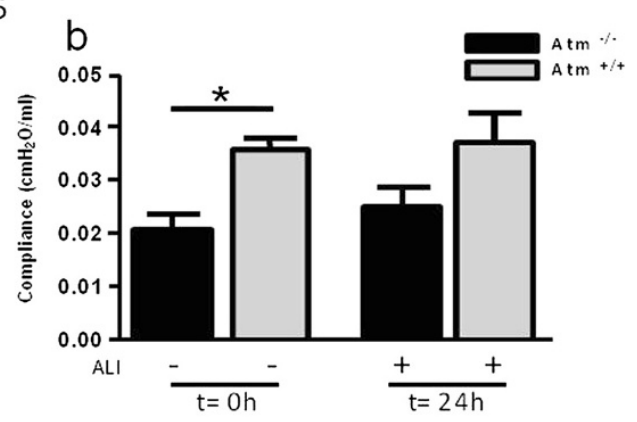

Figure 6 Elevation in lung resistance and increased tissue compliance in $\mathrm{Atm}^{-/-}$mice before and after mucosal injury. Using a flexiVent mouse ventilator, (a) tissue resistance and (b) lung compliance were determined before and 24 hours after acid injury. Values represent the mean \pm S.E.M. for $n \geq 5$ mice. ${ }^{*} P<0.05$ vs. control group.

In other murine models, e.g. an experimental model of colitis, or acute inflammation, ATM deficiency also increases production of pro-inflammatory mediators and regulates leukocyte trafficking to inflammatory sites [38]. Here, ATM deficiency may have contributed to an increased inflammatory response confirmed by levels of several pro-inflammatory mediators in the injured lung.

On the one hand, neutrophilic invasion into the airways is critical to clear pathogens from the site of infection and suppression of the inflammatory response may increase the risk of infection-related adverse events, on the other hand, neutrophilic activation can cause bystander tissue damage that contributes to the pathogenesis of ALI/ARDS [39]. To this end, inhibition of PMN function in animal studies attenuates lung injury induced by models of gastric acid aspiration [40,41]. In this context our data suggest that ATM is a potent regulator of mucosal repair and can promote an array of protective responses for lung catabasis after mucosal injury.
Together, the differences of mucosal immune response and mucosal repair mechanism in $\mathrm{Atm}^{-/-}$mice point to the clinical impact of repetitive mucosal injury by nonpathogen associated mucosal damage in order to explain decline in lung function in our A-T patients. Furthermore, ATM may be a critical immunoregulatory factor dampening the deleterious effects of acute $\mathrm{HCl}$-induced inflammation, being mandatory for systemic genomic stability and homeostasis of the lung epithelial barrier.

\section{Conclusions}

Even though the results of our study are more descriptive, this is the first study showing aggravated non-pathogen damage response after airway mucosal injury in an in vivo AT- mouse model.

$\mathrm{Atm}^{-1-}$ mice are more sensitive to $\mathrm{HCl}$-induced acute inflammation than control mice, especially during remission (24 hours) and up to one week after lung injury, showing lack of repair of incurred damage. ATM therefore can be a

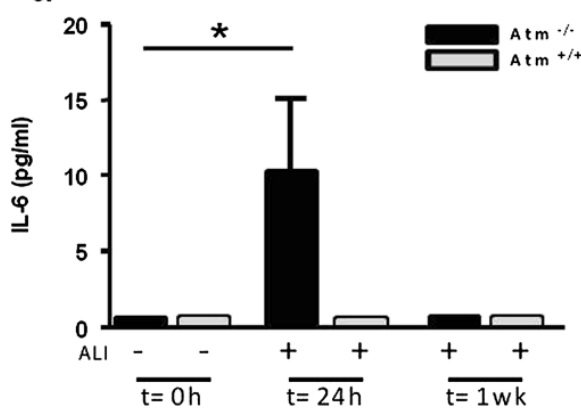

b

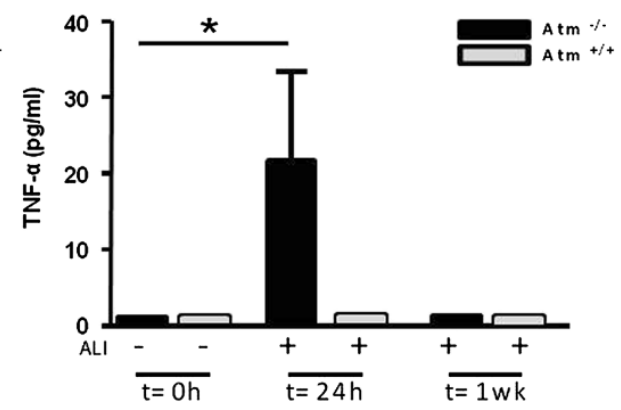

Figure 7 Impact of ATM deficiency on inflammatory mediator levels after ALI. Aliquots of BALFs obtained before ALI, 24 hours and one week after ALI were analyzed by cytometric bead array $(\mathbf{a}, \mathbf{b})$. Values represent the mean \pm S.E.M. for $n \geq 3$ mice. *P $<0.05$ vs. control group. 
inferred to play a critical role in immunoregulation after airway mucosal damage. Further investigations about the role of ATM in achieving homeostasis after airway mucosal injury may help to understand the pathogenesis of A-T lung disease.

\section{Competing interests}

The authors declare that they have no competing interests.

\section{Authors' contributions}

OE and RS designed the protocol. OE, SK, SV, CH, RPD and JP performed the experiments. CD and SW made the histological studies. All authors analyzed and discussed the data. OE and SZ wrote the manuscript. All authors read and approved the final manuscript.

\section{Acknowledgments}

This research was supported in part by the Starke Lunge Stiftung and the German Society of Pediatric Pulmonology. We thank Katrin Krug and Alexandra Hölscher for technical assistance. The content is solely the responsibility of the authors.

\section{Author details}

${ }^{1}$ Pediatric Pulmonology, Allergy and Cystic Fibrosis, Johann Wolfgang Goethe- University, Theodor-Stern-Kai 7, Frankfurt D-60590, Germany. ${ }^{2}$ Institute of Biostatistics and Mathematical Modeling, Johann Wolfgang Goethe-University, Frankfurt, Germany. ${ }^{3}$ Senckenberg Institute of Pathology, Johann Wolfgang Goethe- University, Frankfurt, Germany. ${ }^{4}$ Pediatric Hematology and Oncology, Johann Wolfgang Goethe- University, Frankfurt, Germany. ${ }^{5}$ Division of Infection Immunology, Research Center Borstel, Borstel, Germany.

Received: 21 August 2013 Accepted: 20 May 2014 Published: 29 May 2014

\section{References}

1. Gatti RA, Berkel I, Boder E, Braedt G, Charmley P, Concannon P, Ersoy F, Foroud T, Jaspers NG, Lange K, Lathrop GM, Leppert M, Nakamura Y, O'Connell P, Paterson M, Salser W, Sanal O, Silver J, Sparkes S, Susi E, Weeks DE, Wei S, White R, Yoder F: Localization of an ataxia- telangiectasia gene to chromosome 11q22-23. Nature 1988, 336:577-580.

2. Bredemeyer AL, Sharma GG, Huang CY, Helmink BA, Walker LM, Khor KC, Nuskey B, Sullivan KE, Pandita TK, Bassing CH, Sleckman BP: ATM stabilizes DNA double-strand-break complexes during V(D)J recombination. Nature 2006, 442:466-470.

3. Callen E, Jankovic M, Difilippantonio S, Daniel JA, Chen HT, Celeste A, Pellegrini M, McBride K, Wangsa D, Bredemeyer AL, Sleckman BP, Ried T, Nussenzweig M, Nussenzweig A: ATM prevents the persistence and propagation of chromosome breaks in lympho- cytes. Cell 2007, 130:63-75.

4. Savitsky K, Bar-Shira A, Gilad S, Rotman G, Ziv Y, Vanagaite L, Tagle DA, Smith S, Uziel T, Sfez S, Ashkenazi M, Pecker I, Frydman M, Harnik R, Patanjali SR, Simmons A, Clines GA, Sartiel A, Gatti RA, Chessa L, Sanal O, Lavin MF, Jaspers NG, Taylor AM, Arlett CF, Miki T, Weissman SM, Lovett M, Collins FS, Shiloh Y: A single ataxia telangiectasia gene with a product similar to PI-3 kinase. Science 1995, 268:1749-1753.

5. Crawford TO: Ataxia telangiectasia. Semin Pediatr Neurol 1998, 5:287-294.

6. Lavin MF, Shiloh Y: The genetic defect in ataxia-telangiectasia. Annu Rev Immunol 1997, 15:177-202.

7. Chun HH, Gatti RA: Ataxia-telangiectasia, an evolving phenotype. DNA Repair (Amst) 2004, 3:1187-1196.

8. Gatti RA, Becker-Catania S, Chun HH, Sun X, Mitui M, Lai CH, Khanlou N, Babaei M, Cheng R, Clark C, Huo Y, Udar NC, lyer RK: The pathogenesis of ataxia- telangiectasia. Learning from a Rosetta stone. Clin Rev Allergy Immunol 2001, 20:87-108.

9. Lavin MF: Ataxia-telangiectasia: from a rare disorder to a paradigm for cell signalling and cancer. Nat Rev Mol Cell Biol 2008, 9:759-769.

10. Reichenbach J, Schubert R, Schindler D, Muller K, Bohles H, Zielen S: Elevated oxidative stress in patients with ataxia telangiectasia. Antioxid Redox Signal 2002, 4:465-469.

11. Schubert R, Reichenbach J, Zielen S: Deficiencies in CD4+ and CD8+ T cell subsets in ataxia telangiectasia. Clin Exp Immunol 2002, 129:125-132.
12. Sanal O, Ersoy F, Yel L, Tezcan I, Metin A, Ozyurek H, Gariboglu S, Fikrig S, Berkel Al, Rijkers GT, Zegers BJ: Impaired IgG antibody production to pneumococcal polysaccharides in patients with ataxia-telangiectasia. J Clin Immunol 1999, 19:326-334.

13. Schubert R, Reichenbach J, Rose M, Zielen S: Immunogenicity of the seven valent pneumococcal conjugate vaccine in patients with ataxia- telangiectasia. Pediatr Infect Dis J 2004, 23:269-270.

14. Micol R, Ben Slama L, Suarez F, Le Mignot L, Beaute J, Mahlaoui N, d'Enghien Dubois C, Lauge A, Hall J, Couturier J, Vallée L, Delobel B, Rivier F, Nguyen K, Billette de Villemeur T, Stephan JL, Bordigoni P, Bertrand Y, Aladjidi N, Pedespan JM, Thomas C, Pellier I, Koenig M, Hermine O, Picard C, Moshous D, Neven B, Lanternier F, Blanche S, Tardieu M, Debré M, Fischer A, Stoppa-Lyonnet D, CEREDIH Network Investigators: Morbidity and mortality from ataxia-telangiectasia are associated with ATM genotype. J Allergy Clin Immunol 2011, 28:382-389.

15. Bagley J, Cortes ML, Breakefield XO, lacomini J: Bone marrow transplantation restores immune system function and prevents lymphoma in Atm-deficient mice. Blood 2004, 104:572-578.

16. Lumsden JM, McCarty T, Petiniot LK, Shen R, Barlow C, Wynn TA, Morse HC 3rd, Gearhart PJ, Wynshaw-Boris A, Max EE, Hodes RJ: Immunoglobulin class switch recombination is impaired in Atm-deficient mice. J Exp Med 2004, 200:1111-1121.

17. Pietzner J, Baer PC, Duecker RP, Merscher MB, Satzger-Prodinger C, Bechmann I, Wietelmann A, Del Turco D, Doering C, Kuci S, Bader P, Schirmer S, Zielen S, Schubert R: Bone marrow transplantation improves the outcome of Atm-deficient mice through the migration of ATM-competent cells. Hum Mol Genet 2013, 22:493-507.

18. Barlow C, Hirotsune S, Paylor R, Liyanage M, Eckhaus M, Collins F, Shiloh Y, Crawley JN, Ried T, Tagle D, Wynshaw-Boris A: Atm-deficient mice: a paradigm of ataxia telangiectasia. Cell 1996, 86:159-171.

19. Schubert R, Erker L, Barlow C, Yakushiji H, Larson D, Russo A, Mitchell JB, Wynshaw-Boris A: Cancer chemoprevention by the antioxidant tempol in Atm-deficient mice. Hum Mol Genet 2004, 13:1793-1802.

20. Bott L, Lebreton J, Thumerelle C, Cuvellier J, Deschildre A, Sardet A: Lung disease in ataxia- telangiectasia. Acta Paediatr 2007, 96:1021-1024.

21. McGrath-Morrow SA, Gower WA, Rothblum-Oviatt C, Brody AS, Langston C, Fan LL, Lefton- Greif MA, Crawford TO, Troche M, Sandlund JT, Auwaerter PG, Easley B, Loughlin GM, Carroll JL, Lederman HM: Evaluation and management of pulmonary disease in ataxia-telangiectasia. Pediatr Pulmonol 2010, 45:847-859.

22. Nowak-Wegrzyn A, Crawford TO, Winkelstein JA, Carson KA, Lederman HM: Immunodeficiency and infections in ataxia-telangiectasia. J Pediatr 2004, 144:505-511.

23. Schroeder SA, Swift M, Sandoval C, Langston C: Interstitial lung disease in patients with ataxia-telangiectasia. Pediatr Pulmonol 2005, 39:537-543.

24. Schroeder SA, Zielen S: Infections of the respiratory system in patients with ataxia-telangiectasia. Pediatr Pulmonol 2014, 49:389-399.

25. Lefton-Greif MA, Crawford TO, Winkelstein JA, Loughlin GM, Koerner $\mathrm{CB}$, Zahurak M, Lederman HM: Oropharyngeal dysphagia and aspiration in patients with ataxia-telangiectasia. J Pediatr 2000, 136:225-231

26. Marik PE: Aspiration pneumonitis and aspiration pneumonia. N Engl J Med 2001, 344:665-671

27. Eickmeier O, Seki H, Haworth O, Hilberath JN, Gao F, Uddin M, Croze RH, Carlo T, Pfeffer MA, Levy BD: Aspirin-triggered resolvin D1 reduces mucosal inflammation and promotes resolution in a murine model of acute lung injury. Mucosal Immunol 2013, 6:256-266.

28. Fukunaga K, Kohli P, Bonnans C, Fredenburgh LE, Levy BD: Cyclooxygenase 2 plays a pivotal role in the resolution of acute lung injury. $J$ Immunol 2005, 174:5033-5039.

29. Ehlers S, Reiling N, Hölscher C, Aly S: Measuring immune responses in vivo. Methods in Microbiology 2010, 37:227-269.

30. Buckley RH: Pulmonary complications of primary immunodeficiencies. Paediatr Respir Rev 2004, 5:S225-S233.

31. Crawford TO, Skolasky RL, Fernandez R, Rosquist KJ, Lederman HM: Survival probability in ataxia telangiectasia. Arch Dis Child 2006, 91:610-611.

32. Chopra C, Davies G, Taylor M, Anderson M, Bainbridge S, Tighe P, McDermott EM: Immune deficiency in Ataxia-Telangiectasia: a longitudinal study of 44 patients. Clin Exp Immunol 2014, 176:275-282.

33. Carlo T, Levy BD: Molecular circuits of resolution in airway inflammation. Sci World J 2010, 10:1386-1399. 
34. Schubert R, Schmitz N, Pietzner J, Tandi C, Theisen A, Dresel R, Christmann M, Zielen S: Growth hormone supplementation increased latency to tumourigenesis in Atm-deficient mice. Growth Factors 2009, 27:265-273.

35. McGrath-Morrow SA, Collaco JM, Crawford TO, Carson KA, Lefton- Greif MA, Zeitlin P, Lederman HM: Elevated serum IL-8 levels in ataxia telangiectasia. J Pediatr 2010, 156(4):682-684

36. McGrath-Morrow SA, Lederman HM, Aherrera AD, Lefton-Greif MA, Crawford TO, Ryan T, Wright J, Collaco JM: Pulmonary function in children and young adults with ataxia telangiectasia. Pediatr Pulmonol 2014, 49(1):84-90.

37. Montella S, Mollica C, Finocchi A, Pession A, Pietrogrande MC, Trizzino A, Ranucci G, Maglione M, Giardino G, Salvatore M, Santamaria F, Pignata C: Non invasive assessment of lung disease in ataxia telangiectasia by high- field magnetic resonance imaging. J Clin Immunol 2013, 33(7):1185-1191.

38. Westbrook AM, Schiestl RH: Atm-deficient mice exhibit increased sensitivity to dextran sulfate sodium-induced colitis characterized by elevated DNA damage and persistent immune activation. Cancer Res 2010, 70:1875-1884.

39. Abraham E: Neutrophils and acute lung injury. Crit Care Med 2003, 31:S195-S199.

40. Knight PR, Druskovich G, Tait AR, Johnson KJ: The role of neutrophils, oxidants, and proteases in the pathogenesis of acid pulmonary injury. Anesthesiology 1992, 77:772-778.

41. Folkesson HG, Matthay MA, Hebert CA, Broaddus VC: Acid aspiration- induced lung injury in rabbits is mediated by interleukin-8-dependent mechanisms. J Clin Invest 1995, 96:107-116.

doi:10.1186/1471-2466-14-93

Cite this article as: Eickmeier et al.: Altered mucosal immune response after acute lung injury in a murine model of Ataxia Telangiectasia. BMC Pulmonary Medicine 2014 14:93.

\section{Submit your next manuscript to BioMed Central and take full advantage of:}

- Convenient online submission

- Thorough peer review

- No space constraints or color figure charges

- Immediate publication on acceptance

- Inclusion in PubMed, CAS, Scopus and Google Scholar

- Research which is freely available for redistribution 